\title{
Tree Age and Dominance Patterns in Great Basin Pinyon-Juniper Woodlands
}

\author{
R.J. TAUSCH, N.E. WEST, AND A.A. NABI
}

\begin{abstract}
Prior studies of pinyon-juniper woodlands at a few locations have indicated considerable historical expansion of the trees and loss of understory. Whether these changes are a widespread phenomenon and related to pervasive, rather than local, influences was the question asked by this research. An objective sampling of 18 randomly selected mountain ranges in the Great Basin was undertaken. Tree age and dominance in the pinyon-juniper woodlands showed definite geographical, elevational, and historical trends. The oldest, most tree-dominated woodlands were located in areas of intermediate topography where disturbances may have been less frequent. Populations of both tree species [Pinus monophylla (Torr.) and Juniperus osteosperma (Torr. and Frem.)] were progressively younger and less dominant in both upslope and downslope directions from the intermediate elevations. Tree densities have also historically increased within the oldest woodlands. Pinyon density has increased faster than that of juniper. Approximately $\mathbf{4 0}$ percent of the sampled plots had their trees establishing during the last 150 years. These changes generally coincide with introduction of heavy livestock grazing, tree utilization by the mining industry, and fire suppression that followed settlement of the region. Associated climatic trends were also investigated. The relative importance of these influences on the changes in tree age and dominance cannot be determined without further research. The loss of understory, coincident with increasing tree dominance, has reduced forage production and made the woodlands progressively less susceptible to fire. Barring some major environmental change or management action, this forage reduction and decreased frequency of burning will continue until trees dominate much more area.
\end{abstract}

Pinyon-juniper woodland is an important range type that has apparently increased in area and density over the last century (Plummer 1958, Christensen and Johnson 1964, Murdock and Welsh 1971, West et al. 1975). In the Great Basin, the type now occupies an area of nearly 18 million acres (Tueller et al. 1979).

Although changes in tree dominance in these woodlands have been widely discussed, the few existing studies (Cottam and Stewart 1940, Woodbury 1947, Blackburn and Tueller 1970, Barney and Frischknecht 1974, West et al. 1975), have provided only limited documentation of these changes. Many combinations of natural and man-influenced causes have been proposed (West et al.

\footnotetext{
The authors are former graduate research assistant, professor and former graduate fellow, respectively, Department of Range Science, Utah State University, Logan 84322. Tausch's current address is 401 Manzanita Avenue, Corte Madera, California 94925. Nabi's current address is Department of Range Science, Colorado State University, Fort Collins 80523

This research was performed under a cooperative agreement with the Intermountain Forest and Range Experiment Station, U.S. Forest Service. McIntire-Stennis Forestry Research Act funding was also provided from the Utah Agricultural Experiment Station, of which this is Journal Paper No. 2328. Nabi's contributions were financially supported by the Ministry of Education of the Libyan Arab Republic.

We are indebted to Mr. Robert Bayn for drafting the figures and to many others too numerous to mention individually for assistance in the collection and processing of these data.

Manuscript received November 16, 1979.
}

1975, Burkhardt and Tisdale 1976). Ecologists and land managers have questioned whether the reported thickening of trees in the original stands and invasion of former grasslands and shrubland are a widespread phenomenon controlled by a few wide-reaching factors common to the region or of only local importance. In addition, the rates of change, including the secondary succession resulting from tree re-establishment in areas denuded by tree cutting for mine props and charcoal, has not been totally determined (Lanner 1977, Budy and Young 1979).

The following is a report of our attempts to provide an overview of the spatial and elevational variation of tree age and dominance in the Great Basin pinyon-juniper woodlands by describing existing conditions, historical changes, and apparent rates of change.

\section{Study Area}

The study area lies within the boundaries of the Great Basin portion of the Basin and Range Province (Hunt 1974). An outline of the overall floristics of the Great Basin is discussed in Cronquist et al. (1972), while floristic variation within stands of woodland vegetation currently occurring in the Great Basin has been recently reviewed by West et al. (1978) and Tueller et al. (1979).

The general distribution and dominance of Utah juniper and single needle pinyon varies both elevationally and spatially over the region (Tueller et al. 1979). Woodlands dominated by these species usually occur on the upper bajadas and mountain slopes above the valley floors. Above $2,100 \mathrm{~m}(\sim 7000 \mathrm{ft})$, pinyon is generally the dominant tree and at the upper elevational limits pure stands of pinyon often exist. Juniper generally dominates below $2,100 \mathrm{~m}$ and throughout most of the Great Basin occurs as the only tree in woodlands at the lowest elevational limits. It is also the only tree found at the northern limits of the type. The width of the woodland belt varies considerably, primarily in relation to the differing climatic patterns associated with individual mountain ranges (West et al. 1978).

\section{Methods}

\section{Data Base}

During previous synecological studies (Beeson 1974, West et al. 1978a and b, Tueller et al. 1979) data were gathered on the vegetation, soils, and topography within the pinyon-juniper woodland belts on mountains scattered across the Great Basin. The data used here were derived from a randomly drawn set of 18 of the approximately 200 Great Basin mountain ranges which were sampled at the intermediate level of intensity.

To be sampled, a site had to contain at least 25 pinyon and/or juniper trees per hectare (10 per acre) with at least one tree in the mature size-age-form class (Blackburn and Tueller 1970). These criteria kept samples from extending too far into ecotones, yet allowed a good coverage of the sites which can definitely sustain pinyon-juniper woodlands.

Plots were located on broad, even slopes facing the cardinal 
directions and elevationally placed at $200 \mathrm{~m}(\sim 600 \mathrm{ft})$ contour intervals up and down slope from a baseline of $2,000 \mathrm{~m}(-6560 \mathrm{ft})$. This provided an objective means of plot location that reflected the average conditions on each range. The plots were not located on topographically anomalous : areas or on sites with evidence of recent fires, extensive tree cutting, chaining, or cabling. Sampling involved 133 plots on 18 mountain ranges (Fig. 1 and Table 1).

The center of the lower end of each measured 20 by $50-\mathrm{m}$ macroplot (long axis up slope) was marked and temporary markers were placed at the corners of the macroplot and at the ends of five randomly located $20-\mathrm{m}$ transects bisected by the $50-\mathrm{m}$ center line.

Tree density (except seedlings) was recorded by size-age-form class (Blackburn and Tueller 1970) for the entire macroplot. Two trees representing each of the available size-age-form classes of each species found closest to the intersection of the first transect and the baseline were measured and then cut. This was duplicated for the intersection of the fifth transect and the baseline. These trees were measured for height and average crown diameter. Stump cross sections were collected at a maximum of $1 \mathrm{dm}$ above the ground. The growth rings on these basal stem sections were counted for age estimates. A total of 1,026 juniper and 1,290 pinyon trees were cut and aged.

Tree cover for a plot was estimated by taking an average of the crown areas of the trees in each size-age-form class measured and cut and multiplying by the total number of trees in each respective size-age-form class counted over the entire plot. Tree seedling density was collected in ten contiguous 2 by $2-\mathrm{m}$ microplots on each transect.

Shrub cover data were collected from ten 1 by $2-\mathrm{m}$ microplots, also on each transect. The projected foliar cover of the shrub species was estimated to the nearest $2 \%$ (Daubenmire 1959). Cover data for the grasses and forbs were collected from twenty, 3 by 6-m microplots spaced evenly along each transect. Because of their indefinite crowns, the cover of perennial grasses was recorded by basal area. Forb cover was estimated similarly to shrubs. On each plot the shrub, grass, and forb cover was summed for an understory total, and the cover of the tree species was summed for an overstory total. The physiographic features of elevation, slope, and aspect were also recorded.

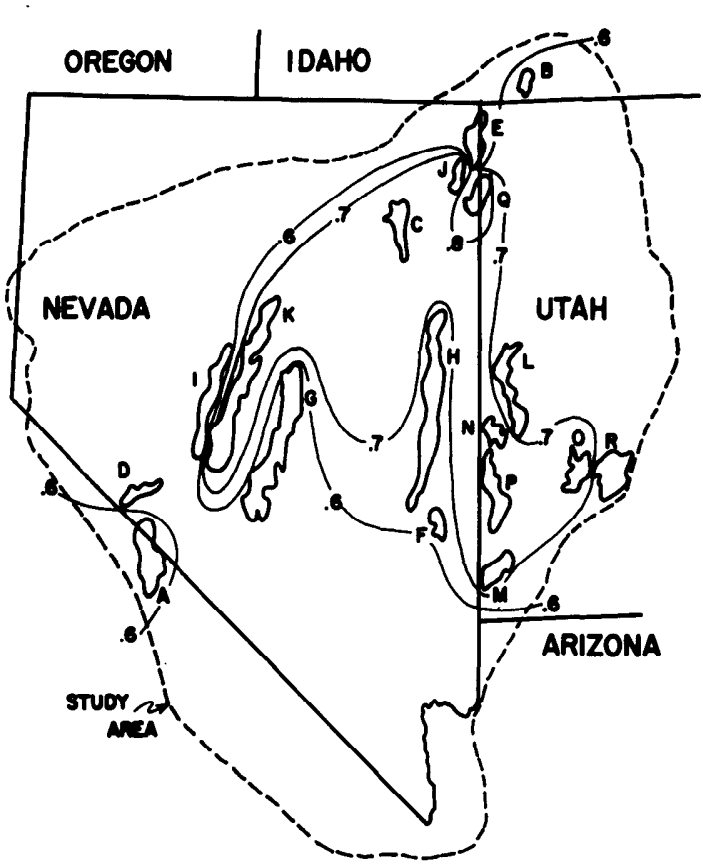

Fig. 1. Map of the study area (outside boundary), the particular mountain ranges sampled (the lower boundaries are the same as in Cronquist et al. 1972), and isolines of their average tree dominance. The isolines encircle ranges of equal or greater value. The range names corresponding to each letter and their average tree dominance indices are listed in Table 1.

\section{Data Analysis}

The one past attempt at a classification of secondary succession in the Great Basin pinyon-juniper woodlands (Blackburn and Tueller 1970) was based on plots obtained from a much smaller area. Their plots varied by less than $20 \%$ in total vegetal cover. As a result, their average cover values generally agree with their visually determined successional or dominance classes. The plots used here, however, ranged in total cover from just under $12 \%$ to nearly $80 \%$, a far greater range in site quality making such a subjective determi-

Table 1. Mountain ranges used in this study, ordered by state, and their year of sampling, number of plots, average tree dominance, and cover-weighted average ages for pinyon and juniper.

\begin{tabular}{|c|c|c|c|c|c|c|}
\hline \multirow{2}{*}{$\begin{array}{l}\text { Map code for } \\
\text { Figure } 1\end{array}$} & \multirow[b]{2}{*}{ State and range } & \multirow[b]{2}{*}{ Year sampled } & \multirow[b]{2}{*}{ Number of stands } & \multirow{2}{*}{$\begin{array}{c}\text { Average } \\
\text { successional status }\end{array}$} & \multicolumn{2}{|c|}{ Cover weighted mean age } \\
\hline & & & & & Pinyon & Juniper \\
\hline A & $\begin{array}{l}\text { California } \\
\text { White Mountains }\end{array}$ & 1972 & 7 & .62 & 149 & 303 \\
\hline B & $\begin{array}{l}\text { Idaho } \\
\text { Black Pine Range }\end{array}$ & 1972 & 5 & .62 & Zero & 82 \\
\hline $\begin{array}{l}\text { C } \\
\text { D } \\
\text { E } \\
\text { F } \\
\text { G } \\
\text { H } \\
\text { I } \\
\text { J } \\
\text { K }\end{array}$ & $\begin{array}{l}\text { Nevada } \\
\text { E. Humboldt Range } \\
\text { Excelsior Range } \\
\text { Goose Creek Range } \\
\text { Highland Range } \\
\text { Monitor Range } \\
\text { Schell Creek Mtns. } \\
\text { Shoshone Range } \\
\text { Toana Range } \\
\text { Toiyabe Range }\end{array}$ & $\begin{array}{l}1972 \\
1972 \\
1972 \\
1972 \\
1972 \\
1972 \\
1972 \\
1972 \\
1972\end{array}$ & $\begin{array}{r}6 \\
4 \\
4 \\
15 \\
10 \\
8 \\
12 \\
5 \\
9\end{array}$ & $\begin{array}{l}.73 \\
.58 \\
.55 \\
.60 \\
.58 \\
.76 \\
.48 \\
.72 \\
.79\end{array}$ & $\begin{array}{r}130 \\
135 \\
\text { Zero } \\
143 \\
141 \\
122 \\
88 \\
132 \\
132\end{array}$ & $\begin{array}{c}279 \\
\text { Zero } \\
96 \\
249 \\
145 \\
183 \\
133 \\
130 \\
147\end{array}$ \\
\hline $\begin{array}{l}\text { L } \\
\mathbf{M} \\
\mathbf{N} \\
\mathbf{O} \\
\mathbf{P} \\
\mathbf{Q} \\
\mathbf{R}\end{array}$ & $\begin{array}{l}\text { Utah } \\
\text { Confusion Range } \\
\text { Enterprise-Beryl Hills } \\
\text { Garrison Hills } \\
\text { Mineral Mtns. } \\
\text { Needle Range } \\
\text { Pilot Range } \\
\text { Tushar Range }\end{array}$ & $\begin{array}{l}1972 \\
1972 \\
1972 \\
1972 \\
1972 \\
1972 \\
1972\end{array}$ & $\begin{array}{r}4 \\
7 \\
2 \\
7 \\
12 \\
9 \\
7\end{array}$ & $\begin{array}{l}.67 \\
.70 \\
.73 \\
.74 \\
.76 \\
.83 \\
.66\end{array}$ & $\begin{array}{r}231 \\
88 \\
146 \\
62 \\
81 \\
140 \\
70\end{array}$ & $\begin{array}{r}379 \\
156 \\
418 \\
122 \\
179 \\
203 \\
88\end{array}$ \\
\hline
\end{tabular}


nation of tree dominance inadequate. With the greatly differing absolute plant densities, cover, size, and frequency that were encountered, relative scales of overstory dominance and understory suppression based on the climax pattern concept of Whittaker (1973) were needed for accurate comparisons between plots. The method adopted assumed that trees are the climax dominants (Blackburn and Tueller 1970) and that eventually a reduced understory exists as the plots approach maturity. As soon as a tree dies, other trees present begin to use up the space and other resources freed by its death (Tausch and West, in prep.).

To judge tree dominance objectively, the fraction of understory cover replaced by trees was divided by the total percent understory cover in the absence of trees to yield an index of tree dominance:

$$
\text { Dominance index }=(a-y) / a
$$

where $a=$ percent understory cover without trees and $y=$ percent understory cover with trees at the time of sampling. An estimate of $a$ was determined from a modification of the standard linear regression formula:

$$
y=a-b x
$$

or transposed:

$$
a=y+b x
$$

where $b=$ the slope of the overstory-understory tradeoff and $x=$ the percent tree cover at sampling. The dominance index for a plot was obtained by combining equations (1) and (3):

$$
\text { Dominance index }=\frac{(y+b x)-y}{y+b x}=\frac{b x}{y+b x}
$$

When an overstory to understory evaluation is done by simple relative percent cover, the value of $b$ in (4) equals -1.0 . The data available (West et al. 1978a, Tueller et al. 1979) indicated that the slope is generally shallower than -1.0 . A value of $b$ was empirically derived from a series of plots from a site in southwestern Utah that covered the seral spectrum from almost no trees to full tree dominance (Tausch 1980). These are the only data of this type known to be available. These data were collected using the same plot size and collection techniques as the rest of the data. A highly significant linear relationship in the overstory-understory tradeoff was obtained ( $r^{2}=0.89, P \leq .001$; Fig. 2). The value of $b$ from this analysis $(-0.75)$ was used in equation (4) to estimate the dominance index of each plot. For the general types of analyses in which the data were used, the value of $b$ can range widely without changing the interpretation of the results.

The range in possible dominance index values was divided into five equal classes $(0.0-0.2,0.2-0.4,0.4-0.6,0.6-0.8,0.8-1.0)$. Each

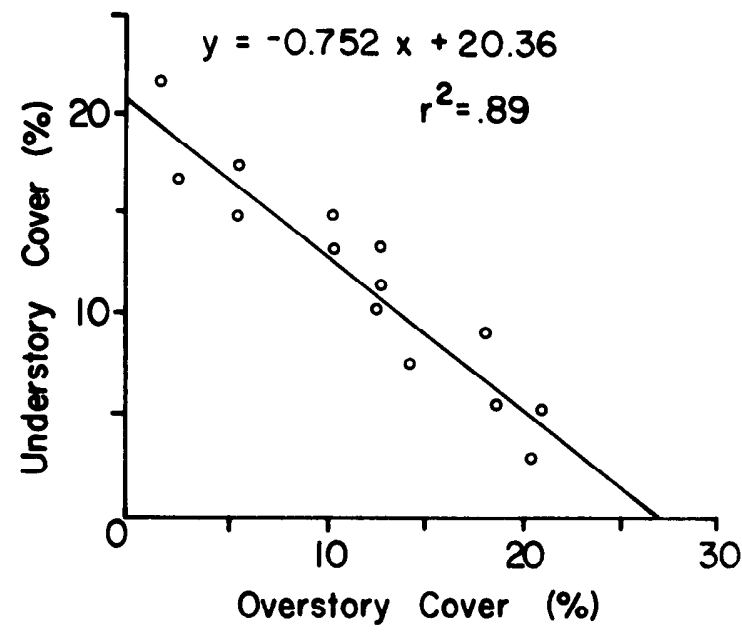

Fig. 2. Simple linear regression analysis of tree to understory cover (\%) over a full sere of increasing tree dominance for one site on the eastern flank of Indian Peak, western Beaver County, Utah, (Tausch 1980). plot was assigned to one of these five classes according to the calculated index value. The average density of each tree species in each class was then determined.

An average tree dominance index was computed for each aspect on each mountain range and for the entire range. An average dominance index and standard error value for each average were also determined for each of the $200-\mathrm{m}$ elevation intervals. Because of small sample size, the two $1,600-\mathrm{m}$ plots were combined with the $1,800-\mathrm{m}$ plots and the one $2,800-\mathrm{m}$ plot with the $2,600-\mathrm{m}$ plots.

Two estimates were made of the age of the overstory trees on each plot. The first, the age of the oldest sampled tree of each species, was an estimate of when the trees of each species first became established on the plot (or re-established following perturbation). The second age determination was the cover-weighted average age of each tree species on each plot. This was an estimate of the average of the trees of either species that dominate the cover of that species (the time period when most of the dominant trees of each species on a plot became established). This value was computed for each plot according to the formula:

$$
\text { Cover Weighted Average Age }=\Sigma C_{\mathrm{i}} A_{\mathrm{i}} / \Sigma C_{\mathrm{i}}
$$

where $C_{\mathrm{i}}=$ cover the $i^{\text {th }}$ size-age-form class and $A_{\mathrm{i}}=$ the average age of the sampled trees of the species in the $i^{\text {ith }}$ size-age-form class.

An average age of the oldest tree of each species and an average cover-weighted age for each tree species was also determined for each aspect of each sampled mountain range and for the entire mountain range. An average for the two age measures and a standard error for each average was also computed for each $200-\mathrm{m}$ elevation interval. The 1,600-m and 1,800-m and the 2,600- and 2,800-m elevations were again combined.

\section{Results and Discussion}

\section{Tree Dominance Patterns}

The most tree-dominated plots (class $0.8-1.0$ ) were also the most abundant, comprising $40.6 \%$ of the total. This was over twice the total number of plots in the two classes with the lowest dominance indices $(0.0-0.2=7.5 \%$ and $0.2-0.4=9.8 \%$ ) and about equal to the sum of the two classes that are intermediate in dominance (0.4-0.6 $=17.3 \%$ and $0.6-0.8=24.8 \%$ ). Part of the abundance of plots with a high tree dominance was the result of the sampling criteria involving minimum tree size and number (methods section). Most of it, however, appears to be a reflection of the actual dominance patterns existing in the Great Basin.

Overall, pinyon dominated the tree cover in approximately twothirds of the plots sampled (Tueller et al. 1979). Pinyon-dominated

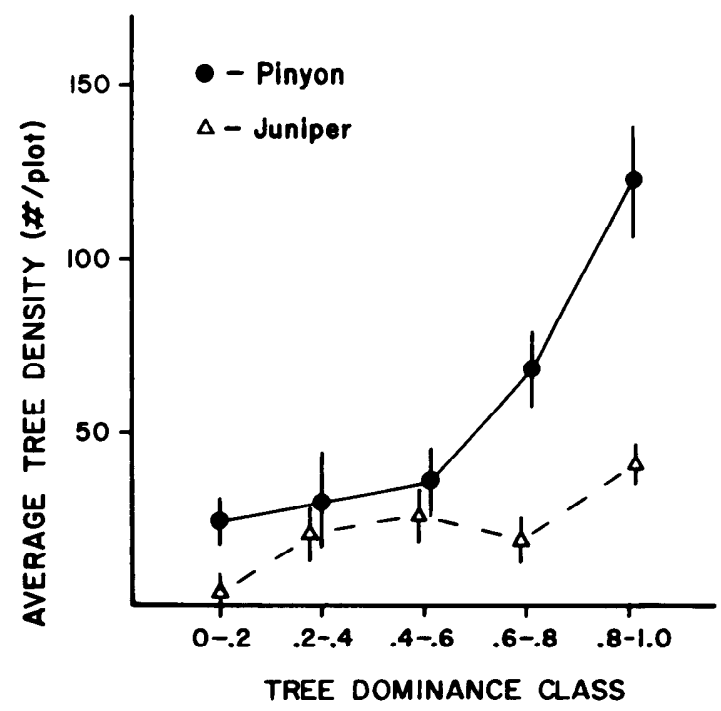

Fig. 3. Average pinyon and juniper density in plots of each dominance class. Data from all mountain ranges combined. Vertical bars equal one standard error of mean. 
plots outnumbered the juniper-dominated plots by about the same 2 to 1 margin in all but the 0.6 to 0.8 dominance index class, where about $1 / 5$ of the plots were juniper-dominated. This result is discussed further in connection with tree establishment rates.

Distinct tree density differences were also evident between dominance classes. The average density of pinyon generally increased with increasing tree dominance at a much faster rate than juniper did (Fig. 3). Since the two trees are similar in size, increasing tree dominance for the entire Basin is apparently more the result of an increase in pinyon than juniper density.

Overall, as the trees matured the understory was largely eliminated whether the overstory was pinyon, juniper, or a mix of the two tree species. This pattern agrees with previous studies of small areas (Blackburn and Tueller 1970, West et al. 1975).

\section{Geographic and Elevational Influences on Tree Dominance}

Geographically, the highest average dominance occurred on the ranges of east-central and northeastern Nevada (Fig. 1). The ranges of west-central Nevada and some of the ranges near the Wasatch Front and at the northern limits of the type had relatively low average tree dominance. Average tree dominance for each aspect on each mountain range showed only small differences from the overall average for each aspect, however, with west slopes the highest $(0.70)$, north slopes the lowest $(0.66)$, and east and south slopes intermediate $(E=0.68, \mathrm{~S}=0.67)$.

From an average value of 0.62 at $1,800 \mathrm{~m}$, the dominance index for each $200-\mathrm{m}$ elevational interval climbed to a peak of 0.76 at $2,000 \mathrm{~m}$ and then declined to a low of 0.43 at $2,600 \mathrm{~m}$ (Fig. 4). The variation in tree dominance was largest at the two lowest elevation intervals, decreased to the mid-elevations, and increased again with increasing elevation, largely in response to changing sample sizes. The dominance of the woodlands was greatest at the middle elevations. The man-caused disturbances described by Lanner (1977) and Budy and Young (1979) may be responsible for this high variation at the lowest elevations. The elevational distributions of tree dominance among the four major aspects were similar in shape to the distribution in Figure 4 where all four aspects were combined, but were slightly displaced according to the previously discussed aspect averages. Downslope invasion was more advanced than upslope. This is possibly due to the shorter growing season, more adverse winter climatic conditions, and the greater competitive ability of the understory species found at the higher elevations (St. Andre et al. 1964), and the history of man-caused disturbances at the lower elevations.

\section{Tree Establishment Rates}

In addition to the level of tree dominance in a plot, some general

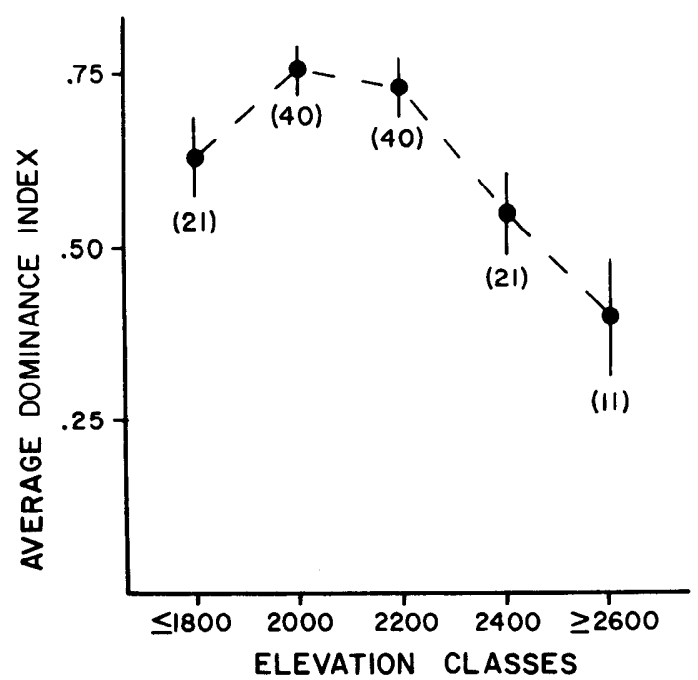

Fig. 4. Average tree dominance for plots at each elevation interval. Data are from all mountain ranges combined. Vertical bars equals one standard error of mean. The numbers in parenthesis equal the number of plots sampled. idea of the time elapsed in reaching its current status is often important. Several factors are involved in this determination. If no trees were present on a site when tree establishment began, the age of the oldest tree is an approximate indicator of the total time elapsed in the development of the overstory. The rate of establishment of individual trees, however, may not necessarily be uniform over time. Frequently, most of the trees can become established over a relatively short period. The period of maximum tree establishment may not coincide with the period of initial establishment, but still provides the most important age components of the established trees.

If a few older trees survive a disturbance, their ages will be not indicative of the age of the period of major tree establishment. The existence of these older trees usually indicates a thickening of a savanna situation. A lack of older trees, however, does not indicate that the existing trees are on a previously unoccupied area.

To aid in interpreting these possible differences, both the age of the oldest sampled tree of each species and the cover-weighted average age for each species was determined on each plot. The latter value approximates the time period when the dominant trees became established. A general description of the history of tree establishment on each plot and then for the region as a whole was obtained by comparing the two ages.

All the plots were grouped by both their cover-weighted average ages and age of their oldest tree (Fig. 5). The past 200 years was divided into eight 25-year intervals. Because of the smaller sample size, the trees from 200 to 600 years of age were divided into eight 50 -ycar age classes. The few trees older than 600 years of age were combined into a single age class. Because of the different age class intervals in Figure 5, only classes of equal width or size class can be directly compared.

A total of $49 \%$ of the plots with pinyon had their pinyon cover dominated by trees less than 100 years old, $59 \%$ by trees less than 125 years old, and $71 \%$ by trees less than 150 years old (Fig. 5a). The pinyon cover on the remaining plots was dominated by trees up to 400 years of age. The largest number of plots occurred in the 50 to 75 year age class.

A total of $40 \%$ of the plots with juniper had their juniper cover dominated by trees less than 125 years old and $48 \%$ by trees less than 150 years old. In the remaining plots the juniper cover was dominated by trees up to nearly 600 years old.

Thirty-nine percent of the plots sampled had an overstory cover (of either or both species) dominated by trees less than 100 years old, $49 \%$ by trees less than 125 years old, and $59 \%$ by trees less than 150 years old. On over one-half of the sampled plots, the overstory cover was dominated by trees that were post-settlement in age. The highest level of tree establishment occurred from 1870 to 1920, the period when impact by European settlers was greatest (Blackburn and Tueller 1970, Budy and Young 1979).

Sixty-four percent of the plots with a maximum cover-weighted average age for either or both species of up to 100 years had a successional index greater than 0.5 . Between 100 and 150 years of age, $71 \%$ had a dominance index of about 0.5 . Overall, two-thirds of the plots with maximum cover-weighted ages of up to 150 years had dominance indices greater than 0.5 . The increase in tree dominance was apparently rapid on many plots once tree establishment had occurred.

A cover-weighted average age for pinyon of less than 125 years associated with juniper with a cover-weighted average age greater than 200 years occurred on $7 \%$ of the plots. Another $4 \%$ of the plots had a cover-weighted average age for pinyon between 126-175 years associated with juniper with a cover-weighted average age greater than 200 years. The age difference between these groups was due to the inclusion of a few older pinyon. These plots (11\%) seem to represent areas where increasing tree density was occurring in former juniper savanna situations.

The distributions of the oldest tree of each species in each plot had similar patterns (Fig. 5b). In $30 \%$ of the plots with pinyon, the oldest pinyon tree was less than 100 years old, in $48 \%$ less than 125 years old, and in $53 \%$ less than 150 years old. In $24 \%$ of the plots 


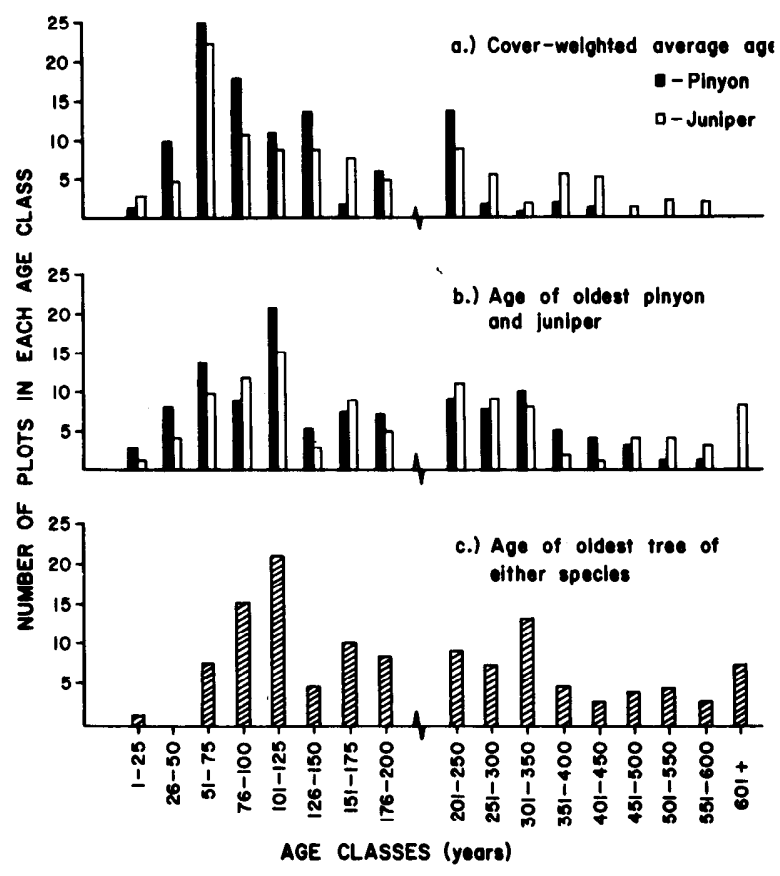

Fig. 5. Distribution of sample plots according to their cover-weighted average age (a) and age of the oldest tree (b) of pinyon and juniper and for the oldest tree of either species in each plot (c).

with juniper, the oldest juniper was less than 100 years old, in $38 \%$ less than 125 years old, and in $41 \%$ was less than 150 years old.

In $19 \%$ of the sampled plots, the oldest tree of either species was less than 100 years old (Fig. 5c), in 36\%, less than 125 years old, and in $40 \%$ of the plots, the oldest tree was less than 150 years old. The historical increase in tree density apparently began almost simultaneously over the Great Basin. The reduced proportion of juniper to pinyon-dominated plots in the $0.6-0.8$ dominance class may have occurred where the plots were dominated by the slower growing juniper and had insufficient time to reach this stage of succession (Fig. 3).

Some early seral stands were missed because the trees were too small and/or too sparse to meet the sampling criteria. These trees were probably also under 150 years of age. If these areas could be included, the magnitude of woodland expansion would be greater than the previous results indicate.

In the time period from 1845 to 1895 , the initial establishment of the oldest tree sampled occurred in more plots than in any similar period before or after. Thcy represented approximately $30 \%$ of the sa mpled plots or, based on the total acreage of Tueller et al. (1979), nearly 6 million acres.

The period of primary tree establishment has been attributed to a number of likely causal factors that occurred concomitantly. These include warmer temperature trends developing from 1850 through 1960 (Wahl and Lawson 1970, LaMarche 1973), the wetter conditions in the last half of the 19th century (Wahl and Lawson 1970, La Marche 1974), the period of grcatest livestock numbers (Blackburn and Tueller 1970), tree harvesting associated with the mining industry (Lanner 1977, Budy and Young 1979) and a prior history of periodic fires (Barney and Frischknecht 1974). The decline in tree establishment over the last 50 years may be due to the saturation of available sites by earlier tree establishment. If trees were not present on any of these sites at the beginning of the period of accelerated tree establishment, then during this period trees became established on approximately an additional six million acres. If trees were present on all of the sites prior to the beginning of the period and then removed by the various mancaused disturbances described by Lanner (1977) and Budy and Young (1979), this would represent the removal of all trees from about 100,000 acres a year for the entire 50 -year period. The truth is somewhere between these extremes. Unfortunately, charcoal

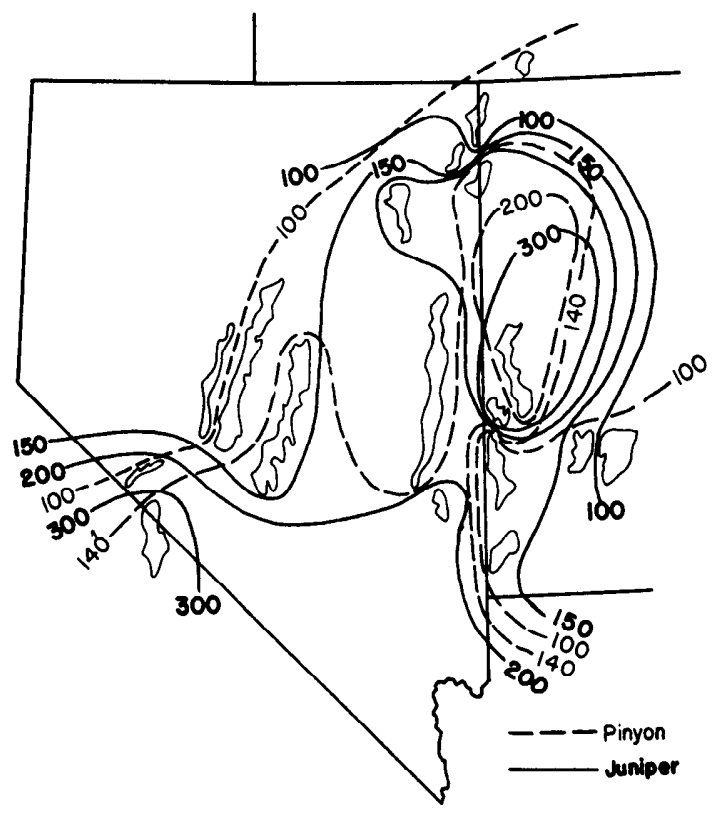

Fig. 6. Isolines of the average cover-weighed age (years) of juniper and pinyon interpolated between sampled mountain ranges. The lines encircle ranges of equal or greater value. The average ages for the ranges are listed in Table 1 .

harvesters cut all the larger living trees and snags to the ground surface level (Lanner 1976). More frequent fires in prehistorical times (Barney and Frischknecht 1974) likely destroyed dead and downed trees. Strong physical evidence of prior woodland occupation in stumps and snags is therefore largely lacking. Further research will be required to conclusively determine the patterns involved in the change and to separate the relative importance of the several possible causal factors in this thickening and expansion of the pinyon-juniper type.

Average cover-weighted ages for each tree species for each mountain range (Table 1) were plotted and ranges with equal or greater value enclosed by isolines (Fig. 6). The youngest trees of both species were found in central and western Nevada, along the northern boundary of the type, or along the Wasatch Front. The oldest average ages were found on the mountain ranges of the drier areas of the southern Great Basin and around the Great Salt Lake Desert. The distribution of the age of the oldest sampled tree was essentially the same.

An average cover-weighted age was determined for all the plots at each 200 meter elevation interval (Fig. 7a). The maximum cover-weighted average age of both species occurred at the 2,200-m elevation interval. Pinyon peaked at a cover-weighted average age of 148 years and juniper at 226 years. Except for the 2,600-m elevation, juniper ranged from 35 to 75 years older than pinyon. The average age of the oldest sampled pinyon peaked at 223 years, and juniper peaked at 292 years, both at 2,000-m in elevation (Fig. $7 b)$. The variation in age generally increased with increasing elevation. The 2,200-m elevation interval was also one of the two most common intervals sampled (Fig. 4).

Optimum conditions for pinyon and juniper longevity evidently occur between the 2,000 and 2,400-m elevation intervals. At these optimum clevations, however, pinyon was the dominant overstory species.

An average age of over 200 years of the oldest trees at the middle elevations indicated that both species of trees have existed over most of the middle elevation belt for a considerable period of time. Natural and/or man-caused disturbances may have been at these elevations. The regular reduction in both cover-weighted average and the age of the oldest tree of both species with increasing and decreasing elevation away from the middle elevations indicated that the more recent establishment of trees in these areas has possibly been under common causal mechanisms operating sim- 

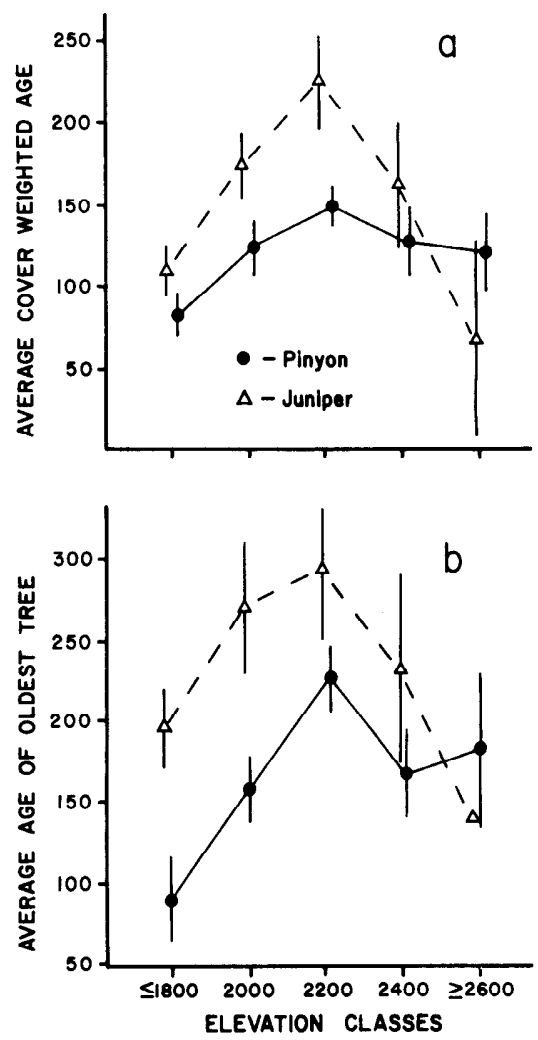

Fig. 7. Relationship of average cover-weighted age (a) and age of oldest tree (years) (b) to elevations sampled. Vertical bars correspond to one standard error.

ilarly at both the upper and lower elevations.

\section{Conclusions}

Pinyon dominated most of the woodland sites sampled and was responsible for most of the increase in tree density and dominance over the last 150 years. It is apparent that the mid-elevations offer optimum conditions for the persistence of both pinyon and juniper, yet juniper occurs primarily at the lower elevations (Fig. 7). This general existence of juniper dominance at lower elevations appeared to result from pinyon competitively confining juniper to the more marginal, lower elevation sites.

Tree density changes in most of the woodland areas began during the last half of the 19th century. These changes were due largely to an increased density and dominance of the trees, primarily pinyon, in an upward and downward elevational spread from the middle elevations where the oldest trees and densest woodlands are generally found. Substantial reductions in the forage available in these woodlands for both game and livestock have apparently occurred during the last 50 to 70 years and are still occurring as a result of this increase in trees. The loss of understory has reduced the amounts of more easily burnable fuel, and the frequency of fires has apparently diminished, adding to the rapidity and area of change. Barring some major environmental change or management action, this forage reduction and decreased frequency of burning will probably continue to occur until trees dominate most of the sites favorable to their survival.

How much of the area now containing young trees represents establishment in new areas and how much represents the reestablishment of areas where tree destruction occurred during settlement remains to be determined by further studies.

\section{Literature Cited}

Barney, M.A., and N.C. Frischknecht. 1974. Vegetation changes following fire in the pinyon-juniper type of west central Utah. J. Range Manage. 17:91-96.

Beeson, C.D. 1974. The distribution and synecology of Great Basin pinyonjuniper. M.S. thesis. Univ. of Nevada, Reno. 91 p.

Blackburn, W.H., and P.T. Tueller. 1970. Pinyon and juniper invasion in black sagebrush communities in east-central Nevada. Ecology 51:841848 .

Budy, J.D., and J.A. Young. 1979. Historical use of Nevada's pinyonjuniper woodlands. J. Forest History 23:113-121.

Burkhardt, J.W., and E.W. Tisdale. 1973. Nature and successional status of western juniper vegetation in Idaho. J. Range Manage. 22:202-207.

Burkhardt, J.W., and E.W. Tisdale. 1976. Causes of juniper invasion in southwestern Idaho. Ecology 57:472-484.

Christensen, E.W., and H.B. Johnson. 1964. Presettlement vegetation in eastern Juab and Millard Counties, Utah. Brigham Young Univ., Sci. Bull. Biol. Ser. 4:1-3.

Cottam, W.P., and G. Stewart. 1940. Plant succession as a result of grazing and of meadow desiccation by erosion since settlement in 1862. J. Forest. 38:613-626.

Cronquist, A., A.H. Holmgren, N.H. Holmgren, and J.A. Reveal. 1972. Intermountain Flora. Vol. 1. Hafner Publ. Co., Inc., N.Y. 269 p.

Daubenmire, R.F. 1960. A canopy coverage method of vegetation analysis. Northwest Sci. 33:48-64.

Hunt, C.B. 1974. The natural regions of the United States and Canada. Freeman, San Francisco. 725 p.

LaMarche, V.C., Jr. 1973. Holocene climatic variations inferred from tree-line fluctuations in the White Mountains, California. J. Quat. Res. 3:632-660.

LaMarche, V.C., Jr. 1974. Paleoclimatic inferences from long tree-ring records. Science 183:1043-1048.

Lanner, R.M. 1976. The tree that made Nevada's silver. p. 443-444. In: S.W. Paher (ed.) Nevada Official Bicentennial Book. Nevada Publ., Las Vegas.

Lanner, R.M. 1977. The eradication of pinyon-juniper woodland: Has the program a legitimate purpose? Western Wildlands 4:12-17.

Murdock, J.R., and S.L. Welsh. 1971. Land use in Wah Wah and Pine Valleys, western Utah. Brigham Young Univ. Sci. Bull. Biol. Ser. 12:25 p.

Plummer, A.P. 1958. Restoration of juniper-pinyon ranges in Utah. Soc. Amer. Forest Proc. Ann. Mtg. p. 207-211.

St. Andre, G., H.A. Mooney, and R.D. Wright. 1965. The pinyon woodland zone in the White Mountains of California. Amer. Midl. Natur. 73:225-239.

Tausch, R.J. 1980. Allometric analysis of plant growth in woodland communities. Ph.D. dissertation, Utah State Univ., Logan. 140-141 p.

Tausch, R.J., and N.E. West. Secondary succession in pinyon-juniper woodlands: An examination of processes and mechanisms (in prep.).

Tueller, P.T., C.D. Beeson, R.J. Tausch, N.E. West, and K.H. Rea. 1979. Pinyon-juniper woodlands of the Great Basin: Distribution, Flora, Vegetal Cover. U.S. Forest Serv. Res. Pap. INT-229. 22 p.

Wahl, E.W., and T.L. Lawson. 1970. The climate of the mid-nineteenth century United States compared to the current normals. Monthly Weather Rev. 98:259-265.

West, N.E., K.H. Rea, and R.J. Tausch. 1975. Basic synecological relationships in pinyon-juniper woodlands. p. 41-58, In: G.F. Gifford and F.E. Busby (eds.). The pinyon-juniper ecosystem: A symposium. Utah Agr. Exp. Sta., Logan, Utah.

West, N.E., R.J. Tausch, K.H. Rea, and P.T. Tueller. 1978a. Phytogeographical variation within pinyon-juniper woodlands of the Great Basin. p. 119-136. In: K.T. Harper and J.L. Reveal (coord.). Intermountain Biogeography: A symposium. Great Basin Naturalist Memoirs 2, Brigham Young Univ., Provo, Utah.

West, N.E., R.J. Tausch, K.H. Rea., and A.R. Southard. 1978 b. Soils associated with pinyon-juniper woodlands of the Great Basin, p. 68-88. In: C.T. Youngberg (ed.). Forest Soils and Land Use. Proc. Fifth North American Forest Soils Conf., Colorado State Univ., Fort Collins.

Whittaker, R.H. 1973. Climax: concept and recognition. p. 137-154. In: R. Knapp (ed.), Vegetation Dynamics, Vol. 8, Handbook of Vegetation Science. Dr. W. Junk, The Hague, Netherlands.

Woodbury, A.N. 1947. Distribution of pigmy conifers in Utah and northwest Arizona. Ecology 28:113-126. 